\title{
Chemistry of 2-(arylazo) phenolate complexes of osmium. Synthesis, structure and redox properties
}

\author{
Falguni Basuli ${ }^{\mathrm{a}}$, Shie-Ming Peng ${ }^{\mathrm{b}}$, Samaresh Bhattacharya ${ }^{\mathrm{a}, *}$ \\ ${ }^{a}$ Department of Chemistry, Inorganic Chemistry Section, Jadavpur University, Calcutta 700032, India \\ ${ }^{\mathrm{b}}$ Department of Chemistry, National Taiwan University, Taipei, Taiwan, R.O.C.
}

Received 21 January 1998; accepted 8 July 1998

\begin{abstract}
Reaction of five 2-(arylazo)phenol ligands (abbreviated in general as Hap-R, where $\mathrm{H}$ stands for the phenolic proton) with $\left[\mathrm{Os}(\mathrm{bpy})_{2} \mathrm{Br}_{2}\right]$ has afforded complexes of type $\left[\mathrm{Os}^{\mathrm{II}}(\mathrm{bpy})_{2}(\mathrm{ap}-\mathrm{R})\right]^{+}$, which have been isolated as the perchlorate salts. The complexes are diamagnetic (low-spin $\mathrm{d}^{6}, S=0$ ) and in acetonitrile solution shows several MLCT transitions in the visible region. Structure of the $\left[\mathrm{Os}(\mathrm{bpy})_{2}(\mathrm{ap}-\mathrm{Me})\right)_{\mathrm{ClO}_{4}}$ complex has been determined by X-ray crystallography. The 2-(arylazo)phenolate anion is coordinated to osmium as a bidentate $\mathrm{N}, \mathrm{O}$-donor forming a five-membered chelate ring and the $\mathrm{OsN}_{5} \mathrm{O}$ coordination sphere is distorted octahedral. Cyclic voltammetry shows a reversible osmium(II)-osmium(III) oxidation in the range of 0.37-0.51 V vs SCE followed by an irreversible osmium(III)-osmium(IV) oxidation in the range of $1.36-1.50 \mathrm{~V}$ vs SCE. These oxidation potentials are sensitive to the electronic nature of the substituent $\mathrm{R}$ in the 2-(arylazo)phenolate ligands. Three one-electron reductions of the coordinated bpy ligands are also displayed on the negative side of SCE below $-1.0 \mathrm{~V}$. Chemical or electrochemical oxidation of the $\left[\mathrm{O} s^{\mathrm{II}}(\mathrm{bpy})_{2}(\mathrm{ap}-\right.$ $\mathrm{R}) \mathrm{ClO}_{4}$ complexes affords brownish-yellow $\left[\mathrm{Os}^{\mathrm{III}}(\mathrm{bpy})_{2}(\mathrm{ap}-\mathrm{R})\right]^{2+}$ species, which have been isolated as the perchlorate salts. These complexes are one-electron paramagnetic (low-spin $\mathrm{d}^{5}, S=1 / 2$ ) and in acetonitrile solution show LMCT transitions in the visible region. Reduction of the brownish-yellow $\left[\mathrm{Os}^{\mathrm{III}}(\mathrm{bpy})_{2}(\mathrm{ap}-\mathrm{R})\right]\left(\mathrm{ClO}_{4}\right)_{2}$ complexes gives back the respective brown $\left[\mathrm{Os}{ }^{\mathrm{II}}(\mathrm{bpy})_{2}(\mathrm{ap}-\right.$ $\mathrm{R}) \mathrm{ClO}_{4}$ complexes. (C) 1999 Elsevier Science Ltd. All rights reserved.
\end{abstract}

Keywords: Osmium; 2-(arylazo)phenolates; synthesis; Structure; Redox properties

\section{Introduction}

The chemistry of osmium has been receiving continuous attention [1-18] largely because of the interesting redox properties exhibited by its complexes. Osmium offers a wide range of oxidation states, the stability and interconvertibility of which are directed by the coordination environment around the metal ion. Complexation of osmium by ligands of different types is of particular importance in this respect. In the present study, which has originated from our recent interest in the chemistry of osmium [19-21], 2-(arylazo)phenols (1) have been used as the principal ligand. These ligands are abbreviated in general as Hap- $\mathrm{R}$, where $\mathrm{H}$ stands for the dissociable phenolic proton and $\mathrm{R}$ is the substituent on the 2-(arylazo)phenol ligand. The 2-(arylazo)phenolate anions usually bind metal ions as bidentate N,O-coordinator forming stable chelate ring, the size of which is reported to be six (2) in almost all cases [22-30] with one

\footnotetext{
* Corresponding author.
}

exception where the ring size is speculated to be either six or five (3) [31]. However, instances are also known where these ligands coordinate metal ions as dianionic tridentate $\mathrm{C}, \mathrm{N}, \mathrm{O}$-donors (4) affording organometallic complexes [32]. It may be noted here that while the ruthenium chemistry of these ligands has been studied well [3236], the analogous osmium chemistry appears to remain unexplored. Herein we wish to report our studies on a group of osmium complexes having only one coordinated 2-(arylazo)phenolate ligand. To satisfy the remaining four coordination sites of osmium in this Os(ap-R) moiety, 2,2'bipyridine (bpy) has been used as the coligand. The synthesis and characterization of a group of $\left[\mathrm{Os}(\mathrm{bpy})_{2}\right.$ (ap$\mathrm{R}) \mathrm{ClO}_{4}$ complexes and their spectroscopic and electrontransfer properties are described in this paper.

\section{Experimental}

\subsection{Materials}

Osmium tetroxide was purchased from Arora Matthey, Calcutta, India and was converted into 
<smiles>[R]c1ccc(/N=N/c2cc(C)ccc2O)cc1</smiles>

1<smiles>[R]c1ccc(/N=N/N=C2/Oc3ccc(C)cc32)cc1</smiles>

3<smiles>[M]COc1ccc(C)cc1/N=N/c1ccc([R])cc1</smiles>

2

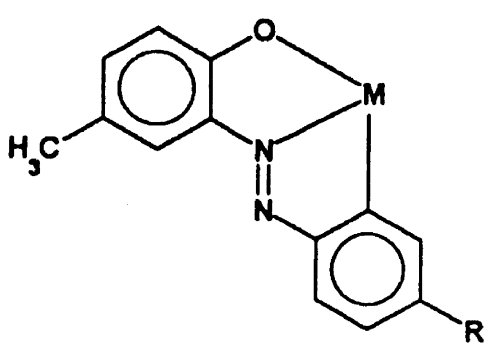

4

$0.16 \mathrm{mmol})$. The solution was then heated at reflux for $6 \mathrm{~h}$. After being cooled to room temperature, a saturated solution of $\mathrm{NaClO}_{4}\left(0.5 \mathrm{~cm}^{3}\right)$ was added to it and the volume of the solution was reduced to about $15 \mathrm{~cm}^{3}$ under reduced pressure. The solution was then kept in the refrigerator for $24 \mathrm{~h}$. $\left[\mathrm{Os}(\mathrm{bpy})_{2}(\mathrm{ap}-\mathrm{H})\right] \mathrm{ClO}_{4} \cdot \mathrm{H}_{2} \mathrm{O}$ precipitated as a dark brown microcrystalline solid, which was collected by filtration, washed with little ice-cold water and dried in vacuo over $\mathrm{P}_{4} \mathrm{O}_{10}$. Purification of the product was done by recrystallization from dichloromethane-hexane solution. The yield was $100 \mathrm{mg}$ $(81 \%)$.

\subsection{2. $\left[\mathrm{Os}^{\mathrm{III}}(\mathrm{bpy})_{2}(\mathrm{ap}-\mathrm{H})\right]\left(\mathrm{ClO}_{4}\right)_{2} \cdot \mathrm{H}_{2} \mathrm{O}$}

To an acetonitrile solution of $\left[\mathrm{Os}(\mathrm{bpy})_{2}(\mathrm{ap}-\right.$ $\mathrm{H}) \mathrm{ClO}_{4} \cdot \mathrm{H}_{2} \mathrm{O}(100 \mathrm{mg}, 0.12 \mathrm{mmol})$ was added one drop of bromine. The colour of the solution immediately changed to brownish-yellow. A saturated aqueous solution of $\mathrm{NaClO}_{4}\left(0.5 \mathrm{~cm}^{3}\right)$ was then added. Upon partial evaporation of the solvents dark crystalline precipitate of $\left[\mathrm{Os}(\mathrm{bpy})_{2}(\mathrm{ap}-\mathrm{H})\right]\left(\mathrm{ClO}_{4}\right)_{2} \cdot \mathrm{H}_{2} \mathrm{O}$ separated out, which was collected by filtration, washed with little ice-cold water and dried in vacuo over $\mathrm{P}_{4} \mathrm{O}_{10}$. Purification of the product
[Os (bpy $)_{2} \mathrm{Br}_{2}$ ] (100 mg, $\left.0.15 \mathrm{mmol}\right)$ was dissolved in $3: 1$ EtOH-water $\left(40 \mathrm{~cm}^{3}\right)$ and to the solution was added Hap$\mathrm{H}(35 \mathrm{mg}, 0.16 \mathrm{mmol})$ followed by $\mathrm{NEt}_{3} \quad(16 \mathrm{mg}$, 
was done by recrystallization from acetonitrile-benzene solution. The yield was $85 \mathrm{mg}(75 \%)$.

\subsection{Physical measurements}

Microanalyses $(\mathrm{C}, \mathrm{H}, \mathrm{N})$ were performed using a Perkin-Elmer $240 \mathrm{C}$ elemental analyser. Infrared spectra were obtained on a Perkin-Elmer 783 spectrometer with samples prepared as $\mathrm{KBr}$ pellets. Electronic spectra were recorded on a Simadzu UV 1601 spectrophotometer. Magnetic susceptibilities were measured using a PAR 155 vibrating sample magnetometer fitted with a Walker Scientific L75FBAL magnet. ${ }^{1} \mathrm{H}$ NMR spectra were obtained on a Brucker AC-200 NMR spectrometer using TMS as the internal standard. ESR spectral studies were done using a varian E-109C spectrometer fitted with a quartz Dewar for measurements at $77 \mathrm{~K}$ (liquid nitrogen). Solution electrical conductivities were measured using a Philips PR 9500 bridge with a solute concentration of $10^{-3} \mathrm{M}$. Electrochemical measurements were made using a PAR model 273 potentiostat. A platinum disc or graphite working electrode, a platinum wire auxiliary electrode and an aqueous saturated calomel reference electrode (SCE) were used in a three electrode configuration. A platinum wire gauze working electrode was used in the coulometric experiments. A RE $0074 X-Y$ recorder was used to trace the voltammograms. Electrochemical measurements were performed under a dinitrogen atmosphere. All electrochemical data were collected at $298 \mathrm{~K}$ and are uncorrected for junction potentials.

\subsection{Crystallography}

Single crystals of $\left[\mathrm{Os}(\mathrm{bpy})_{2}(\mathrm{ap}-\mathrm{Me})\right] \mathrm{ClO}_{4} \cdot \mathrm{H}_{2} \mathrm{O}$ were grown by slow diffusion of hexane into a dichloromethane solution of the complex. Selected crystal data and data collection parameters are given in Table 1 . The

Table 1

Crystallographic data for $\left[\mathrm{Os}(\mathrm{bpy})_{2}(\mathrm{ap}-\mathrm{Me})\right] \mathrm{ClO}_{4} \cdot \mathrm{H}_{2} \mathrm{O}$

\begin{tabular}{ll}
\hline Formula & $\mathrm{C}_{34} \mathrm{H}_{31} \mathrm{~N}_{6} \mathrm{O}_{6} \mathrm{ClOs}$ \\
fw & 845.30 \\
Space group & monoclinic, $\mathrm{P} 2_{1} / \mathrm{c}$ \\
$a(\AA)$ & $13.5891(23)$ \\
$b(\AA)$ & $17.780(3)$ \\
$c(\AA)$ & $14.9040(17)$ \\
$\beta\left({ }^{\circ}\right)$ & $114.479(13)$ \\
$V\left(\AA^{3}\right)$ & $3277.3(9)$ \\
$Z$ & 4 \\
$\mathrm{Crystal}$ size $(\mathrm{mm})$ & $0.20 \times 0.25 \times 0.40$ \\
$T(\mathrm{~K})$ & 298 \\
$\mu\left(\mathrm{cm}^{-1}\right)$ & 40.247 \\
$R_{\mathrm{f}}$ & 0.038 \\
$R_{\mathrm{w}}$ & 0.033 \\
$\mathrm{GOF}$ & 1.23 \\
\hline
\end{tabular}

$R_{\mathrm{f}}=\Sigma|| F_{\mathrm{o}}|-| F_{\mathrm{c}}|/ \Sigma| F_{\mathrm{o}} \mid . \quad R_{\mathrm{w}}=\left[\Sigma w\left(\left|F_{\mathrm{o}}\right|-\left|F_{\mathrm{c}}\right|\right)^{2} / \Sigma w\left(F_{\mathrm{o}}\right)^{2}\right]^{1 / 2}$. unit cell dimensions were determined by a least-squares fit of 25 machine-centered reflections $\left(19.30<2 \theta<26.54^{\circ}\right)$. Data were collected on an Enraf-Nonjus CAD-4 diffractometer using graphite monochromated Mo $\mathbf{K}_{\alpha}$ radiation $(\lambda=0.7107 \mathrm{~A})$ by $\theta-2 \theta$ scans within the angular range $3.0-50.0^{\circ}$. Three standard reflections, measured every $3600 \mathrm{~s}$ of X-ray exposure, showed no significant intensity variation over the course of data collection. Xray data reduction and structure solution and refinement were done using the NRCVAX package. The structure was solved by the Patterson method. Final cycles of refinement converged with discrepancy indices of $R_{\mathrm{f}}=0.038$ and $R_{\mathrm{w}}=0.033$.

\section{Results and discussion}

\section{1. $\left[O s^{I I}(b p y)_{2}(a p-R)\right]^{+}$complexes}

Displacement of the two bromide ligands from the coordination sphere of $\left[\mathrm{Os}(\mathrm{bpy})_{2} \mathrm{Br}_{2}\right]$ by the 2-(arylazo)phenolate ligands in $3: 1$ ethanol-water afforded complexes of type $\left[\mathrm{Os}(\mathrm{bpy})_{2}(\mathrm{ap}-\mathrm{R})\right]^{+}$in decent yields, which were isolated as perchlorate salts in the solid state. Some characterization data of the complexes are given in Table 2. Elemental $(\mathrm{C}, \mathrm{H}, \mathrm{N})$ analytical data are in good agreement with the compositions of the complexes. The $\left[\mathrm{Os}(\mathrm{bpy})_{2}(\mathrm{ap}-\mathrm{R})\right]^{+}$complexes are diamagnetic, which corresponds to the +2 state of osmium (low-spin $\mathrm{d}^{6}$, $S=0$ ) in these complexes. ${ }^{1} \mathrm{H}$ NMR spectra of the $\left[\mathrm{Os}(\mathrm{bpy})_{2}(\mathrm{ap}-\mathrm{R})\right]^{+}$complexes were recorded in $\mathrm{CDCl}_{3}$ solution. The aromatic region $(6.0-8.6 \mathrm{ppm})$ of these spectra is rather complex in nature due to overlap of signals and hence assignment of the signals in this region to specific protons has not been possible. However, intensity measurement of these signals corresponds to the total number of aromatic protons present in the respective complexes. In all five $\left[\mathrm{Os}(\mathrm{bpy})_{2}(\mathrm{ap}-\mathrm{R})\right]^{+}$complexes, a distinct methyl resonance is observed near $2.3 \mathrm{ppm}$ which is assigned to the methyl group in the $p$-cresol fragment of ap-R ligands. Additional methyl signals are observed in $\left[\mathrm{Os}(\mathrm{bpy})_{2}(\mathrm{ap}-\mathrm{Me})\right]^{+}$and $\left[\mathrm{Os}(\mathrm{bpy})_{2}(\mathrm{ap}-\mathrm{OMe})\right]^{+}$, respectively, at 2.04 and $3.67 \mathrm{ppm}$, which are due to the methyl and methoxy-methyl group in the arylazo fragment of the ap-Me and ap-OMe ligands.

The molecular structure of $\left[\mathrm{Os}(\mathrm{bpy})_{2}(\mathrm{ap}-\right.$ $\mathrm{Me}) \mathrm{ClO}_{4} \cdot \mathrm{H}_{2} \mathrm{O}$ was determined by X-ray crystallography. A view of the complex cation is shown in Fig. 1 and selected bond distances and angles are listed in Table 3. The coordination sphere around osmium is distorted octahedral, which is reflected in the three trans-angles and twelve cis-angles. The 2-(arylazo)phenolate ligand is coordinated to osmium as a bidentate N,O-donor forming a five-membered chelate ring with a bite angle of $79.8^{\circ}$. To the best of our knowledge, this represents the first example of a structurally characterized 2-(aryl- 
azo)phenolate complex forming a five-membered chelate ring. To investigate the origin of the formation of such five-membered chelate ring, instead of the rather usual six-membered ring [22-30], a computer model ${ }^{1}$ of $\left[\mathrm{Os}(\mathrm{bpy})_{2}(\mathrm{ap}-\mathrm{R})\right]^{+}$was constructed forcing a six-membered chelate ring formation by the 2-(arylazo)-phenolate ligand and assuming the ap- $\mathrm{R}$ ligand to be planar in this coordination mode [24]. The model (Figure 2) clearly shows that in this coordination mode, the phenyl ring of the arylazo fragment of the ap- $\mathrm{R}$ ligand comes in contact with one pyridine ring of one bpy ligand causing instability to the complex. The observed coordination mode of the 2-(arylazo) phenolate ligand therefore appears to be directed by its steric interaction with one bpy ligand. The Os- $\mathrm{N}$ and Os- $\mathrm{O}$ distances are quite normal and so is the phenolic $\mathrm{C}-\mathrm{O}$ distance [20]. However, the $\mathrm{N}-\mathrm{N}$ distance is short, only 1.241(9) $\AA$. In $\mathrm{Os}^{\mathrm{II}}$-azo complexes, where the azo function is part of the chelate ring, the azo $\mathrm{N}-\mathrm{N}$ distance is usually longer than ideal $\mathrm{N}=\mathrm{N}$ double bond due to back donation from the low-spin $\mathrm{d}^{6}$ metal center to the $\pi^{*}$-orbital of the azo ligand [43]. The short $\mathrm{N}-\mathrm{N}$ distance observed in this $\left[\mathrm{Os}(\mathrm{bpy})_{2}(\mathrm{ap}-\mathrm{Me})\right]^{+}$complex is attributable to the non-participation of this azo group in $\pi$-bonding with the metal $t_{2}$ orbitals. As the properties of all five $\left[\mathrm{Os}(\mathrm{bpy})_{2}(\mathrm{ap}-\mathrm{R})\right]^{+}$complexes are similar (vide infra), the other four $\left[\mathrm{Os}(\mathrm{bpy})_{2}(\mathrm{ap}-\mathrm{R})\right]^{+}$ complexes are assumed to have a similar structure as $\left[\mathrm{Os}(\mathrm{bpy})_{2}(\mathrm{ap}-\mathrm{Me})\right]^{+}$.

Infrared spectra of the $\left[\mathrm{Os}(\mathrm{bpy})_{2}(\mathrm{ap}-\mathrm{R})\right] \mathrm{ClO}_{4}$ complexes show many vibrations of different intensities from $1600 \mathrm{~cm}^{-1}$ downwards. Assignment of all bands to specific vibrations has not been attempted. However, comparison of these spectra with the spectrum of [Os(bpy $)_{2} \mathrm{Br}_{2}$ ] shows the presence of some common vibrations (e.g. vibrations near 1600, 1480, 1460, 1440, $1420,1020,765,730$ and $660 \mathrm{~cm}^{-1}$ ), which are probably due to the common Os(bpy $)_{2}$ moiety. Some additional vibrations are observed in the spectra of the $\left[\mathrm{Os}(\mathrm{bpy})_{2}(\mathrm{ap}-\mathrm{R}) \mathrm{ClO}_{4}\right.$ complexes (e.g. vibrations near $1490,1350,1100,960,835$ and $620 \mathrm{~cm}^{-1}$ ). Of these additional vibrations, the two intense ones observed near 1100 and $620 \mathrm{~cm}^{-1}$ in all these complexes, are assigned to the perchlorate ion. The other new vibrations are obviously due to the coordinated 2-(arylazo) phenolate ligand.

The $\left[\mathrm{Os}(\mathrm{bpy})_{2}(\mathrm{ap}-\mathrm{R})\right] \mathrm{ClO}_{4}$ complexes are soluble in common polar organic solvents like ethanol, acetone, dichloromethane, acetonitrile etc., producing brown solutions. Conductance measurement in acetonitrile solution shows that these complexes behave as 1:1 electrolytes (Table 2), as expected. Electronic spectra of the $\left[\mathrm{Os}(\mathrm{bpy})_{2}(\mathrm{ap}-\mathrm{R}) \mathrm{ClO}_{4}\right.$ complexes have been recorded in acetonitrile solution. Spectral data are presented in Table

\footnotetext{
${ }^{1}$ Computer modelling was done by using part of a software package described later (see end of this section and Ref. [41,42]).
} 


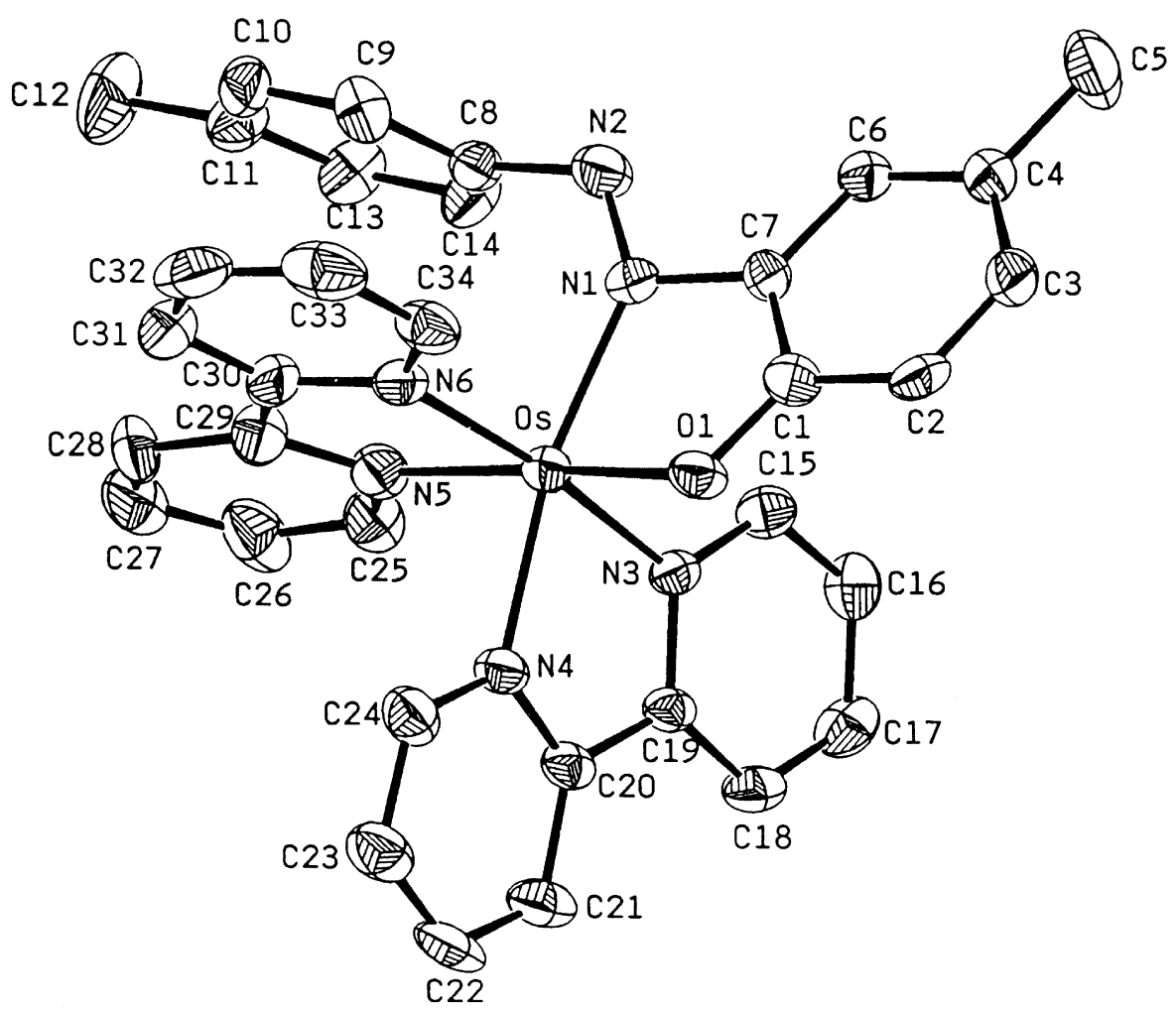

Fig. 1. Structure of $\left[\mathrm{Os}(\mathrm{bpy})_{2}(\mathrm{ap}-\mathrm{Me})\right]^{+}$cation.

Table 3

Selected bond distances and bond angles for $\left[\mathrm{Os}(\mathrm{bpy})_{2}(\mathrm{ap}-\mathrm{Me})\right] \mathrm{ClO}_{4} \cdot \mathrm{H}_{2} \mathrm{O}$

\begin{tabular}{|c|c|c|c|}
\hline \multicolumn{4}{|c|}{ Bond distances $(\AA)$} \\
\hline Os-O1 & $2.078(5)$ & $\mathrm{N} 1-\mathrm{N} 2$ & $1.241(9)$ \\
\hline Os-N1 & $2.038(6)$ & $\mathrm{C} 7-\mathrm{N} 1$ & $1.441(10)$ \\
\hline Os-N3 & $2.072(6)$ & $\mathrm{C} 8-\mathrm{N} 2$ & $1.426(11)$ \\
\hline Os-N4 & $2.067(6)$ & $\mathrm{C} 1-\mathrm{O} 1$ & $1.323(9)$ \\
\hline Os-N5 & $2.032(6)$ & & \\
\hline Os-N6 & $2.063(6)$ & & \\
\hline \multicolumn{4}{|c|}{ Bond angles $\left({ }^{\circ}\right)$} \\
\hline N3-Os-N6 & $172.9(3)$ & & \\
\hline $\mathrm{O} 1-\mathrm{Os}-\mathrm{N} 5$ & $171.69(24)$ & & \\
\hline $\mathrm{N} 1-\mathrm{Os}-\mathrm{N} 4$ & $167.54(25)$ & & \\
\hline $\mathrm{O} 1-\mathrm{Os}-\mathrm{N} 1$ & $79.81(22)$ & O1-Os-N6 & 95.4(3) \\
\hline $\mathrm{O} 1-\mathrm{Os}-\mathrm{N} 3$ & $89.09(21)$ & O1-Os-N4 & $90.93(21)$ \\
\hline $\mathrm{N} 1-\mathrm{Os}-\mathrm{N} 3$ & $93.98(23)$ & N5-Os-N6 & $78.2(3)$ \\
\hline N1-Os-N5 & $105.46(25)$ & N1-Os-N6 & $92.28(23)$ \\
\hline N3-Os-N4 & 77.4(3) & $\mathrm{N} 4-\mathrm{Os}-\mathrm{N} 5$ & $84.73(24)$ \\
\hline N3-Os-N5 & $96.8(3)$ & N4-Os-N6 & $96.9(3)$ \\
\hline
\end{tabular}

2 and a representative spectrum is displayed in Fig. 3. Each complex systematically shows five intense absorptions in the visible region and three absorptions of very high intensity in the ultraviolet region. The absorptions in the ultraviolet region are assigned to transitions within the ligand orbitals. The intense absorptions in the visible region are probably due to allowed metal-to-ligand charge-transfer transitions. Multiple charge-transfer transitions in such mixed-ligand complexes may result from lower symmetry splitting of the metal level, the presence of different acceptor orbitals and from the mixing of singlet and triplet configurations in the excited state through spin-orbit coupling [44-47]. To have a better insight into the nature of these observed electronic transitions, qualitative EHMO calculations have been performed $[41,42]$ on a model of the $\left[\mathrm{Os}(\mathrm{bpy})_{2}(\mathrm{ap}-\mathrm{R})\right]^{+}$ 


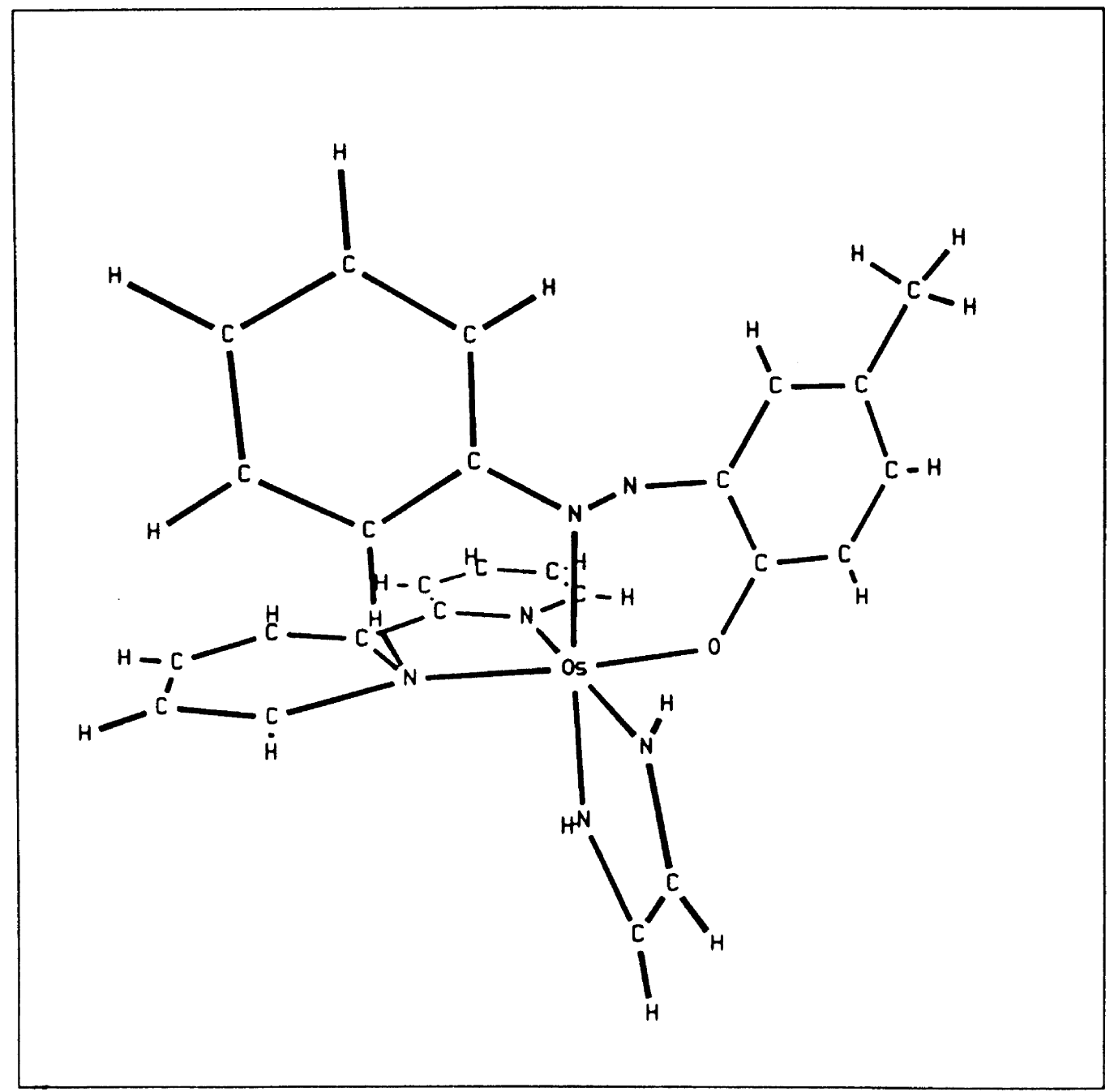

Fig. 2. Computer model of $\left[\mathrm{Os}(\mathrm{bpy})_{2}(\mathrm{ap}-\mathrm{H})\right]^{+}$forcing a six-membered chelate ring formation by the ap-H ligand. Some ring carbon atoms and hydrogen atoms of one bpy ligand have been omitted for clarity.

complexes which was computer generated from $\left[\mathrm{Os}(\mathrm{bpy})_{2}(\mathrm{ap}-\mathrm{R})\right]^{+}$by replacing the aryl group of the arylazo fragment of ap-R ligand by $\mathrm{H}$ and imposing a $\mathrm{C}_{1}$ symmetry. Partial MO diagram is shown in Fig. 4.

The HOMO, HOMO-1 and HOMO-2 of this model are predominantly osmium $\mathrm{t}_{2 \mathrm{~g}}$ in character. The LUMO and LUMO +1 are basically $\pi^{*}$-orbitals of bpy while the $\mathrm{LUMO}+2$ has almost equal contribution from both bpy and the 2-(arylazo) phenolate ligand. The lowest energy $\mathrm{HOMO} \rightarrow$ LUMO transition is therefore a $\mathrm{OS}\left(\mathrm{t}_{2 \mathrm{~g}}\right) \rightarrow$ $\operatorname{bpy}\left(\pi^{*}\right)$ transition. Specific assignment of all observed absorptions based on this MO diagram has not been attempted. However from the MO diagram it is clear that from the three filled orbitals (viz. HOMO, HOMO-1 and HOMO-2) multiple charge transfer transitions may take place to the vacant accepting orbitals (viz. LUMO, $\mathrm{LUMO}+1$ and $\mathrm{LUMO}+2$ ).

\subsection{Cyclic voltammetric studies}

Electron-transfer properties of the $\left[\mathrm{Os}(\mathrm{bpy})_{2}(\mathrm{ap}-\mathrm{R})\right]^{+}$ complexes have been studied in acetonitrile solution ( $0.1 \mathrm{M}$ TEAP) by cyclic voltammetry. All the complexes show two oxidative responses on the positive side of SCE and three reductive responses on the negative side. Voltammetric data are presented in Table 4 and a selected voltammogram is displayed in Fig. 5.

The first oxidative response exhibited by each complex in the range of $0.37-0.51 \mathrm{~V}$ (all potentials are referenced to SCE) is assigned to the osmium(II)-osmium(III) oxidation eq. (1). This oxidation is

$\left[\mathrm{Os}{ }^{I I}(\mathrm{bpy})_{2}(\mathrm{ap}-\mathrm{R})\right]^{+} \rightleftharpoons\left[\mathrm{Os}{ }^{I I I}(\mathrm{bpy})_{2}(\mathrm{ap}-\mathrm{R})\right]^{2+}+\mathrm{e}^{-}$

reversible, characterized by a peak-to-peak separation 


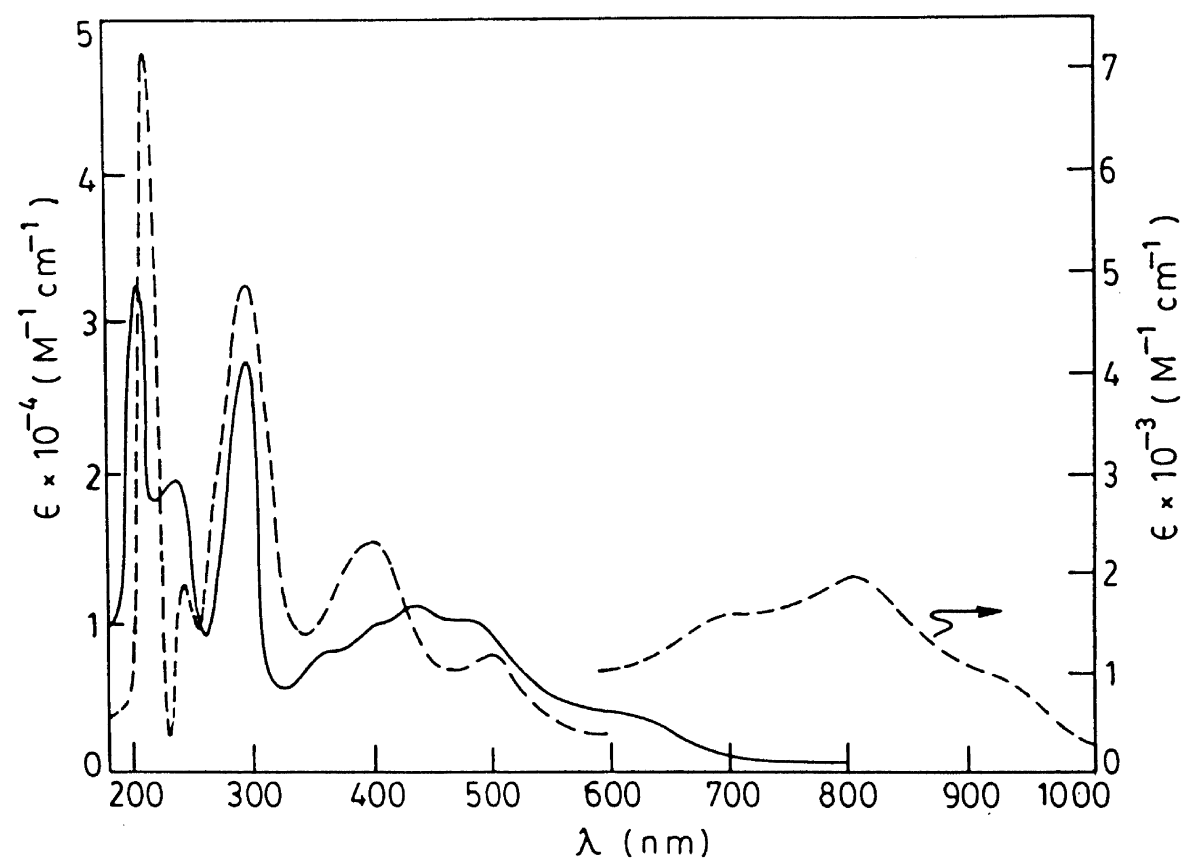

Fig. 3. Electronic spectra of $\left[\mathrm{Os}^{\mathrm{II}}(\mathrm{bpy})_{2}(\mathrm{ap}-\mathrm{H})\right] \mathrm{ClO}_{4}(-)$ and $\left[\mathrm{Os}^{\mathrm{III}}(\text { bpy })_{2}(\mathrm{ap}-\mathrm{H})\right]\left(\mathrm{ClO}_{4}\right)_{2}(---)$ in acetonitrile solution.

$\left(\Delta E_{\mathrm{p}}\right)$ of $60 \mathrm{mV}$ which remains unchanged upon changing the scan rate. The anodic peak current $\left(i_{\mathrm{pa}}\right)$ is almost equal to the cathodic peak current $\left(i_{\mathrm{pc}}\right)$, as expected for a reversible couple. The one-electron nature of this oxidation has been confirmed by constant potential coulometric experiments (vide infra). The osmium(II)osmium(III) oxidation potential in these $\left[\mathrm{Os}(\mathrm{bpy})_{2}\right.$ (ap$\mathrm{R})]^{+}$complexes is observed to be sensitive to the nature of the substituent $\mathrm{R}$ in the ap- $\mathrm{R}$ ligand, the potential increases with increasing electron-withdrawing character of R. The plot of oxidation potentials vs Hammett constant $(\sigma)$ of the substituent $\mathrm{R}$ (the $\sigma$ values [48] used are: $\mathrm{OMe}=-0.27, \quad \mathrm{Me}=-0.17, \quad \mathrm{H}=0.00, \quad \mathrm{Cl}=0.23$, $\mathrm{NO}_{2}=0.78$ ) is linear (Fig. 6) with a $\rho$ value ( $\rho=$ reaction constant of this redox couple [49]) of $0.13 \mathrm{~V}$. This shows that a single substituent, which is five bonds away from the electroactive metal center, can influence the redox potential in a predictable manner. Comparison of the osmium(II)-osmium(III) oxidation potential in the $\left[\mathrm{Os}(\mathrm{bpy})_{2}(\mathrm{ap}-\mathrm{R})\right]^{+}$complexes with that in $\left[\mathrm{Os}(\mathrm{bpy})_{3}\right]^{2+}$ $(0.84 \mathrm{~V})^{2}$ shows that in the $\left.\left[\mathrm{Os}(\mathrm{bpy})_{2} \mathrm{ap}-\mathrm{R}\right)\right]^{+}$complexes, osmium(II)-osmium(III) oxidation is taking place at much lower potentials. This observed lowering of oxidation potential upon replacing one bpy by one 2-(arylazo) phenolate ligand reflects the ability of these phenolate ligands to stabilize the trivalent state of osmium. Similar lowering of redox potentials upon replacing bpy by phenolate ligands in both ruthenium and osmium complexes is documented in literature [20, $36,50,51]$. This further points to the fact that inspite of

\footnotetext{
${ }^{2}$ This oxidation potential has been determined by us.
}

coordination by the soft azo-nitrogen, coordination by phenolate oxygen has been very effective in lowering the osmium(II)-osmium(III) oxidation potential.

A second oxidative response, quasi-reversible in nature, is shown by all the $\left[\mathrm{Os}(\mathrm{bpy})_{2}(\mathrm{ap}-\mathrm{R})\right]^{+}$complexes in the range of $1.36-1.50 \mathrm{~V}$ and is assigned to the osmium(III)-osmium(IV) oxidation [eq. (2)].

$\left[\mathrm{Os}^{I I I}(\mathrm{bpy})_{2}(\mathrm{ap}-\mathrm{R})\right]^{2+} \rightarrow\left[\mathrm{Os}^{I V}(\text { bpy })_{2}(\text { ap- } \mathrm{R})\right]^{3+}+\mathrm{e}^{-}$

The one-electron nature of this oxidation is established by comparing its current height $\left(i_{\mathrm{pa}}\right)$ with that of the osmium(II)-osmium(III) couple. These oxidation potentials $\left(E_{\mathrm{pa}}\right)$ also correlate linearly with $\sigma$ of substituent $\mathrm{R}$ (Fig. 6) and the observed $\rho$ value $(0.13 \mathrm{~V})$ is same as observed in the case of osmium(II)-osmium(III) oxidation, indicating a similar influence of the substituent $\mathrm{R}$ on this osmium(III)-osmium(IV) oxidation.

The three reductive responses, exhibited by the $\left[\mathrm{Os}(\mathrm{bpy})_{2}(\mathrm{ap}-\mathrm{R})\right]^{+}$complexes on the negative side of $\mathrm{SCE}$, are assigned to reductions of the coordinated bpy ligands as shown in eqs. (3-5). It is

$$
\begin{aligned}
& {\left[\mathrm{Os}^{I I}(\mathrm{bpy})_{2}(\mathrm{ap}-\mathrm{R})\right]^{+}+\mathrm{e}^{-} \rightleftharpoons\left[\mathrm{Os}^{I I}(\mathrm{bpy})(\mathrm{bpy})(\mathrm{ap}-\mathrm{R})\right]} \\
& {\left[\mathrm{Os}^{I I}(\mathrm{bpy})(\mathrm{bpy})(\mathrm{ap}-\mathrm{R})\right]+\mathrm{e}^{-} \rightleftharpoons\left[\mathrm{Os}^{I I}(\mathrm{bpy})_{2}(\mathrm{ap}-\mathrm{R})\right]^{-}} \\
& {\left[\mathrm{Os}^{I I}(\mathrm{bpy})_{2}(\text { ap }-\mathrm{R})\right]^{-}+\mathrm{e}^{-}}
\end{aligned}
$$

$$
\rightleftharpoons\left[\mathrm{Os}^{I I}(\mathrm{bpy})(\mathrm{bpy})(\mathrm{ap}-\mathrm{R})\right]^{2-}
$$

well documented in the literature that each bpy ligand can successively accept two electrons in its lowest unoccupied molecular orbital $[52,53]$. Hence, in these $\left[\mathrm{Os}(\mathrm{bpy})_{2}\right.$ (ap$\mathrm{R})]^{+}$complexes four successive one-electron reductions 

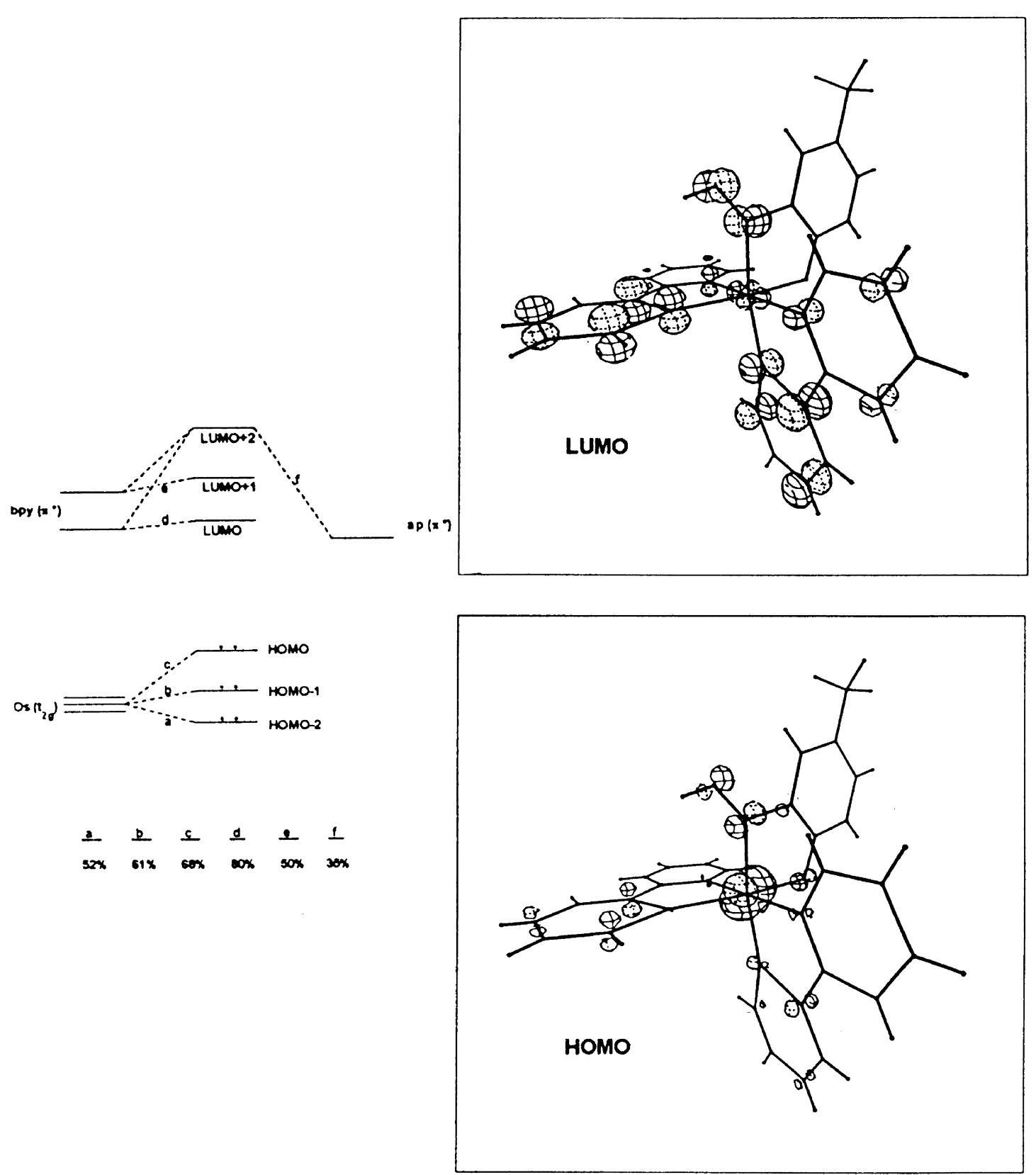

Fig. 4. Qualitative molecular orbital diagram of $\left[\mathrm{Os}(\mathrm{bpy})_{2}(\mathrm{ap}-\mathrm{R})\right]^{+}$.

may be expected, of which three have been experimentally observed. The fourth reduction could not be observed due to solvent cut-off.

\section{3. $\left[\mathrm{Os}^{I I I}(\text { bpy })_{2}(a p-R)\right]^{2+}$ complexes}

The reversible nature of osmium(II)-osmium(III) oxidation in the $\left[\mathrm{Os}(\mathrm{bpy})_{2}(\mathrm{ap}-\mathrm{R})\right]^{+}$complexes shows that the $\left[\mathrm{Os}^{\mathrm{III}}(\mathrm{bpy})_{2}(\mathrm{ap}-\mathrm{R})\right]^{2+}$ species are stable, at least on the cyclic voltammetric time scale. The oxidation potentials are relatively low, which further suggest that the oxidized complexes might also be stable on a longer time scale. To investigate the stability of the $\left[\mathrm{Os}^{\mathrm{III}}(\mathrm{bpy})_{2}(\mathrm{ap}-\right.$ $\mathrm{R})]^{2+}$ complexes, they were electrochemically generated by coulometric oxidation of the $\left[\mathrm{Os}^{\mathrm{II}}(\mathrm{bpy})_{2}(\mathrm{ap}-\mathrm{R})\right]^{+}$species at $0.7 \mathrm{~V}$. The oxidations were smooth and quantitative, resulting in a colour change of brown to brownish-yellow. The brownish-yellow solutions of the $\left[\mathrm{Os}^{\mathrm{III}}(\mathrm{bpy})_{2}(\mathrm{ap}-\mathrm{R})\right]^{2+}$ complexes show identical cyclic voltammograms as their respective precursors, except that the osmium(II)-osmium(III) couple now appears as a reductive response. This indicates that no gross change 
Table 4

Cyclic voltammetric data ${ }^{\mathrm{a}}$ of the $\left[\mathrm{Os}(\mathrm{bpy})_{2}(\mathrm{ap}-\mathrm{R})\right] \mathrm{ClO}_{4}$ complexes

\begin{tabular}{|c|c|c|c|}
\hline \multirow[t]{2}{*}{ Compound } & \multicolumn{3}{|c|}{$E_{1 / 2}^{\mathrm{b}} \mathrm{V}$ vs $\operatorname{SCE}\left(\Delta E_{\mathrm{p}}^{\mathrm{c}}, \mathrm{mV}\right)$} \\
\hline & $\mathrm{Os}^{\mathrm{II} / \mathrm{III}}$ & $\mathrm{Os}^{\mathrm{III} / \mathrm{IV}}$ & bpy reductions \\
\hline$\left[\mathrm{Os}(\mathrm{bpy})_{2}(\mathrm{ap}-\mathrm{OMe})\right] \mathrm{ClO}_{4}$ & $0.37(60)$ & $1.36(90)$ & $-1.17(120),-1.71(90),-2.02(120)$ \\
\hline$\left[\mathrm{Os}(\mathrm{bpy})_{2}(\mathrm{ap}-\mathrm{Me})\right] \mathrm{ClO}_{4}$ & $0.38(60)$ & $1.37(90)$ & $-1.19(100),-1.72(90),-2.04(120)$ \\
\hline$\left[\mathrm{Os}(\mathrm{bpy})_{2}(\mathrm{ap}-\mathrm{H})\right] \mathrm{ClO}_{4}$ & $0.41(60)$ & $1.42(100)$ & $-1.18(80),-1.69(100),-2.05(100)$ \\
\hline$\left[\mathrm{Os}(\mathrm{bpy})_{2}(\mathrm{ap}-\mathrm{Cl})\right] \mathrm{ClO}_{4}$ & $0.43(60)$ & $1.44(90)$ & $-1.15(70),-1.70(80),-2.03(100)$ \\
\hline$\left[\mathrm{Os}(\mathrm{bpy})_{2}\left(\mathrm{ap}-\mathrm{NO}_{2}\right)\right] \mathrm{ClO}_{4}$ & $0.51(60)$ & $1.50(100)$ & $-1.07(60),-1.68(80),-2.08(100)$ \\
\hline
\end{tabular}

a Solvent, acetonitrile; supporting electrolyte, TEAP; scan rate, $50 \mathrm{mV} \mathrm{s}{ }^{-1}$.

${ }^{\mathrm{b}} E_{1 / 2}=0.5\left(E_{\mathrm{pa}}+E_{\mathrm{pc}}\right)$, where $E_{\mathrm{pa}}$ and $E_{\mathrm{pc}}$ are anodic and cathodic peak potentials, respectively.

${ }^{\mathrm{c}} \Delta E_{\mathrm{p}}=E_{\mathrm{pa}}-E_{\mathrm{pc}}$.

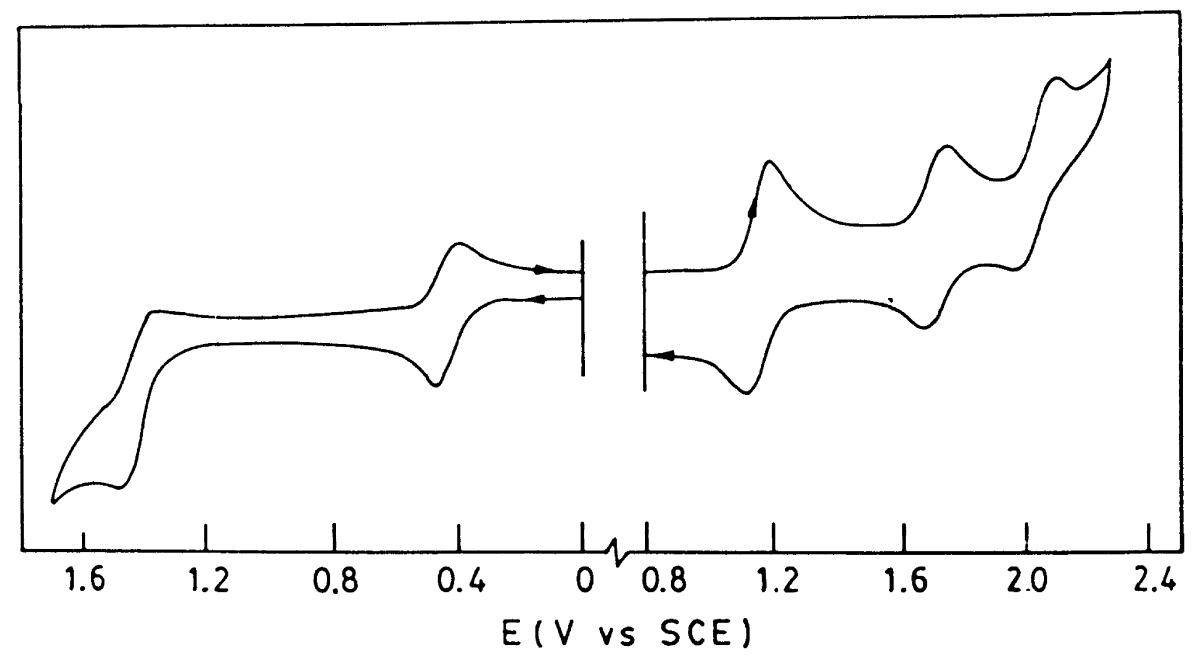

Fig. 5. Cyclic voltammogram of $\left[\mathrm{Os}(\mathrm{bpy})_{2}(\mathrm{ap}-\mathrm{Cl})\right] \mathrm{ClO}_{4}$ in acetonitrile solution $\left(0.1 \mathrm{M}\right.$ TEAP) at a scan rate of $50 \mathrm{mV} \mathrm{s} \mathrm{s}^{-1}$. A platinum working electrode was used for scanning the positive side of SCE and a graphite working electrode was used for scanning the negative side.

in the coordination environment around osmium took place during the oxidation. Coulometric reduction of the brownish-yellow solutions at $0.1 \mathrm{~V}$ gave back brown solutions of the respective $\left[\mathrm{Os}^{\mathrm{II}}(\mathrm{bpy})_{2}(\mathrm{ap}-\mathrm{R})\right]^{+}$complexes, which were identified by their characteristic electronic spectra. Chemical oxidation of the $\left[\mathrm{Os}^{\mathrm{II}}(\mathrm{bpy})_{2}(\mathrm{ap}-\mathrm{R})\right]^{+}$ complexes by bromine in acetonitrile solution also afforded the $\left[\mathrm{Os}^{\mathrm{III}}(\mathrm{bpy})_{2}(\mathrm{ap}-\mathrm{R})\right]^{2+}$ species, which were isolated as the perchlorate salt in the solid state. Characterization data of the $\left[\mathrm{Os}^{\mathrm{III}}(\mathrm{bpy})_{2}(\mathrm{ap}-\mathrm{R})\right]\left(\mathrm{ClO}_{4}\right)_{2}$ complexes are given in Table 5. Composition of these complexes have been confirmed by their microanalytical data. Except small shifts in band positions, the IR spectra of these oxidized complexes are almost identical to their respective $\left[\mathrm{Os}^{\mathrm{II}}(\mathrm{bpy})_{2}(\mathrm{ap}-\mathrm{R})\right] \mathrm{ClO}_{4}$ precursors. The $\left[\mathrm{Os}{ }^{\mathrm{III}}\right.$ $\left.(\mathrm{bpy})_{2}(\mathrm{ap}-\mathrm{R})\right]\left(\mathrm{ClO}_{4}\right)_{2}$ complexes are one-electron paramagnetic, which is in accordance with the +3 oxidation state of osmium (iow-spin $\mathrm{d}^{5}, S=1 / 2$ ) in these complexes.
However, ESR studies show that these $\left[\mathrm{Os}^{\mathrm{III}}(\mathrm{bpy})_{2}\right.$ (ap$\mathrm{R})]\left(\mathrm{ClO}_{4}\right)_{2}$ complexes are ESR-silent. The ESR-inactivity in low-spin $\mathrm{d}^{5}$ complexes is known to result from extensive mixing of the Kramers doublets by strong spin-orbit coupling which gives rise to short electronic relaxation time $[20,54]$. In acetonitrile solution these [Os ${ }^{\text {III }}$ (bpy) $)_{2}$ (ap-R) $]\left(\mathrm{ClO}_{4}\right)_{2}$ complexes behave as 1:2 electrolytes, as expected. Electronic spectra of the $\left[\mathrm{Os}^{\mathrm{III}}\right.$ $\left.(\text { bpy })_{2}(\mathrm{ap}-\mathrm{R})\right]\left(\mathrm{ClO}_{4}\right)_{2}$ complexes have been recorded in acetonitrile solution. Each complex shows several absorptions in the UV, visible and lower energy regions (Table 5 and Fig. 3). The intense absorptions in the UV region are assigned to transitions within the ligand orbitals and those in the visible region to ligand-to-metal charge-transfer transitions. The two relatively less intense absorptions in the lower energy region (803-841 and 916$954 \mathrm{~nm}$ ) could be due to crystal field transitions within the three split $t_{2}$ levels [55]. Chemical reduction of the 

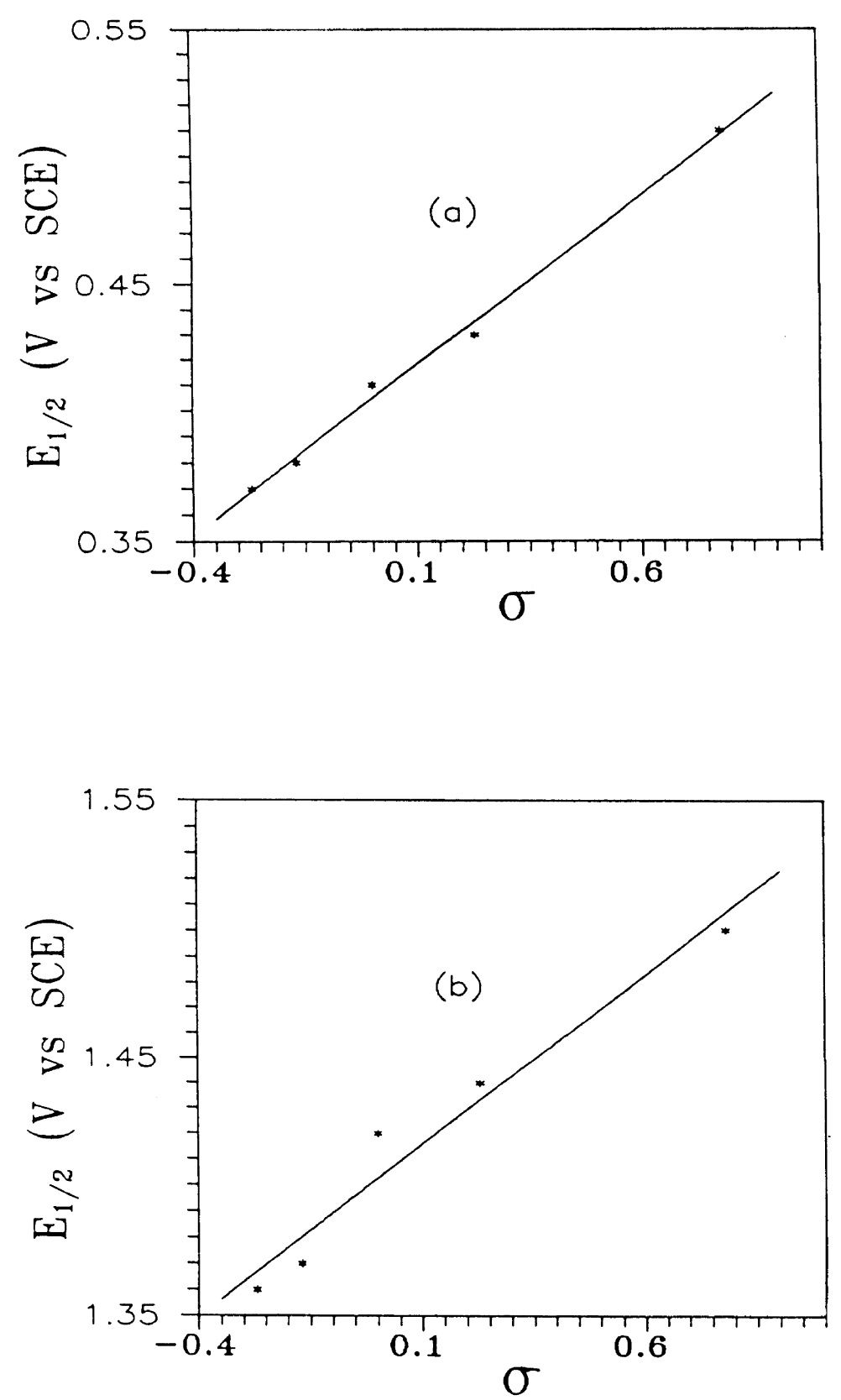

Fig. 6. Least-squares plot of $E_{1 / 2}$ values of (a) $\mathrm{Os}^{\mathrm{II}} / \mathrm{Os}^{\mathrm{III}}$ couple vs $\sigma$ and (b) $\mathrm{Os}^{\mathrm{III}} / \mathrm{Os}^{\mathrm{IV}}$ couple vs $\sigma$.

brownish-yellow $\left[\mathrm{Os}{ }^{\mathrm{III}}(\mathrm{bpy})_{2}(\mathrm{ap}-\mathrm{R})\right]\left(\mathrm{ClO}_{4}\right)_{2}$ complexes in acetonitrile solution by hydrazine quantitatively affords the respective brown $\left[\mathrm{Os}^{\mathrm{II}}(\mathrm{bpy})_{2}(\mathrm{ap}-\mathrm{R})\right]^{+}$complexes. This shows that the osmium(II)-Osmium(III) oxidation eq. (1) is chemically reversible as well.

\section{Conclusion}

The present study on the $\left[\mathrm{Os}(\mathrm{bpy})_{2}(\mathrm{ap}-\mathrm{R}) \mathrm{ClO}_{4}\right.$ complexes reveals that coordination by phenolate oxygen is very effective in stabilizing the higher oxidation states of osmium. The observed shift of about $400 \mathrm{mV}$ in osmium(II)-osmium(III) oxidation potential on going from $\left[\mathrm{Os}(\mathrm{bpy})_{3}\right]^{2+}$ to $\left[\mathrm{Os}(\mathrm{bpy})_{2}(\mathrm{ap}-\mathrm{R})\right]^{+}$indicates that in the osmium complexes having more of these phenolate ligands, this oxidation will be much easier. For example, in $\left[\mathrm{Os}^{\mathrm{II}}(\mathrm{bpy})(\mathrm{ap}-\mathrm{R})_{2}\right]$ and $\left[\mathrm{Os}^{\mathrm{II}}(\mathrm{ap}-\mathrm{R})_{3}\right]^{-}$complexes, the same osmium(II)-osmium(III) oxidation may be expected to appear near 0.0 and $-0.4 \mathrm{~V}$, respectively. Therefore the air-stable oxidation state of osmium in these two complexes will probably be +3 . Studies on these two and other osmium-phenolate complexes are currently in progress. 


\section{Acknowledgements}

Financial assistance received from the Council of Scientific and Industrial Research, New Delhi [Grant No. 01(1408)/196/EMR-II] is gratefully acknowledged. Thanks are also due to the Third World Academy of Sciences for financial support for the purchase of an electrochemical cell system. The authors thank Dr Surajit Chattopadhyay of Vidyasagar University, Midnapore, West Bengal and Dr Rupendranath Banerjee of Jadavpur University, Calcutta, for their help. F. B. thanks the University Grants Commission, New Delhi, for her fellowship.

\section{References}

[1] Seddon KR. Coord Chem Rev 1982;41:159.

[2] Moore DS. Coord Chem Rev 1982;44:127.

[3] Gulliver DJ, Levason W. Coord Chem Rev 1982;46:1.

[4] Seddon EA. Coord Chem Rev 1985;67:243.

[5] Albers MO, Robinson DJ, Singleton E. Coord Chem Rev 1987;79:1.

[6] Thomas NC. Coord Chem Rev 1989;93:225.

[7] Rong D, Hong HG, Kim YI, Krueger JS, Mayer JE, Mallouk TE. Coord Chem Rev 1990;97:237.

[8] Yam VWW, Che CM. Coord Chem Rev 1990;97:93.

[9] Hage R. Coord Chem Rev 1991;111:161.

[10] Collin JP, Guillerez S, Sauvage JP, Barigelletti F, Flamigni L, Cola LD, Balzani V. Coord Chem Rev 1991;111:291.

[11] Cola LD, Barigelletti F, Balzani V, Belser P, Zelewsky AV, Seel C, Frank M, Vogtle F. Coord Chem Rev 1991;111:255.

[12] Constable EC, Housecroft CE. Coord Chem Rev 1993;124:183.

[13] Ward MD. Coord Chem Rev 1993;127:1.

[14] Furue M, Maruyama K, Kanematsu Y, Kushida T, Kamachi M. Coord Chem Rev 1994;132:201.

[15] Barigelletti F, Flamigni L, Balzani V, Collin JP, Sauvage JP, Sour A, Constable EC, Thompson AMWC. Coord Chem Rev 1994;132:209.

[16] Kalyansundaram K, Zakeeruddin SM, Nazeeruddin MK. Coord Chem Rev 1994;132:259.

[17] Richmond MG. Coord Chem Rev 1995;141:63.

[18] Ward MD. Coord Chem Rev 1995;146:99.

[19] Basuli F, Peng SM, Bhattacharya S. Inorg Chem 1997;36:5645.

[20] Basuli F, Peng SM, Bhattacharya S. Polyhedron 1998;17:2191.

[21] Sui K, Bhattacharya S. (submitted).

[22] Haendler HM, Smith GMP. J Am Chem Soc 1940;62:1669.

[23] Ueno K. J Am Chem Soc 1957;79:3066.

[24] Jarvis JAJ. Acta Cryst. 1961;14:961.

[25] Price R. J Chem Soc A 1969;1296.

[26] Kalia KC. Indian J. Chem. 1970;8:1035.

[27] Dyachenko OA, Atovmyan LO, Aldoshin SM. J Chem Soc Chem Commun 1975;105.

[28] Marov IN, Gambarov DG, Belyaeva VK, Guseinov AG, Sokolov AB. Russ. J Inorg Chem 1948;29(10):1452.

[29] Sinha CR, Bandyopadhyay D, Chakravorty A. J Chem Soc Chem. Commun., 1988;468.

[30] Bhawmick R, Biswas H, Bandyopadhyay P. J Orgmet Chem 1995;498:81.

[31] Callis CF, Nielsen NC, Bailar Jr. JC. J Am Chem Soc 1952;74:3461.

[32] Lahiri GK, Bhattacharya S, Mukherjee M, Mukherjee A, Chakravorty A. Inorg Chem 1987;26:3359.

[33] Benson EP, Legg JI. Inorg Chem 1981;20:2504.

[34] Chakravarty J, Bhattacharya S. Polyhedron 1996;15:1047. 
[35] Sinha PK, Chakravarty J, Bhattacharya S. Polyhedron 1996;15:2931.

[36] Pramanik NC, Bhattacharya S. Polyhedron 1997;16:3047.

[37] Dwyer FP, Hogarth JW. Inorg Synth 1957;5:204.

[38] Kober EM, Casper JV, Sullivan BP, Meyer TJ. Inorg Chem 1988;27:4587.

[39] Sawyer DT, Roberts JL, Jr. Experimental Electrochemistry for Chemists. John Wiley, New York, 1974, pp. 167-215.

[40] Walter M, Ramaley L. Anal Chem 1973;45:165.

[41] Maelli C, Proserpio DM. CACAO, Version 4.0. Firenze, Italy, July 1994.

[42] Maelli C, Proserpio DM. J Chem Educ 1990;67:399.

[43] Ghosh BK, Mukhopadhyay A, Ghoswami S, Ray S, Chakravorty A. Inorg Chem 1984;23:4633.

[44] Pankuch BJ, Lacky DE, Crosby GA. J Phys Chem 1980;84: 2061

[45] Ceulemans A, Vanquickenborne LG. J Am Chem Soc 1981;103:2238
[46] Decurtins S, Felix F, Ferguson J, Gudel HU, Ludi A. J. Am. Chem. Soc. 1980;102:4102.

[47] Kober EM, Meyer TJ. Inorg Chem 1982;21:3967.

[48] Hammett LP. Physical Organic Chemistry, 2nd edn. McCraw Hill, New York, 1970

[49] Mukherjee RN, Rajan OA, Chakravorty A. Inorg Chem 1982;21:785.

[50] Bardwell DA, Black D, Jeffery JC, Schatz E, Ward MD. J Chem Soc Dalton Trans 1993;2321.

[51] Pramanik NC, Bhattacharya S. Polyhedron 1997;16:1755.

[52] Vlcek AA. Coord Chem Rev 1982;43:39.

[53] Kahl JL, Hanck KW, DeArmond K. J Phys Chem 1978;82: 540.

[54] Shirin Z, Mukherjee RN. Polyhedron 1992;11:2625.

[55] Lahiri GK, Bhattacharya S, Ghosh BK, Chakravorty A. Inorg Chem 1987;26:4324. 